last month has threatened the very existence of many distinguished men in universities of that country.

The Universities' Committee has also taken on the further responsibility of endeavouring to raise funds for the relief of men of learning and students in Russia. In careful consultation with Dr. Nansen, the committee is establishing those links in Russia which shall ensure a wise distribution of the funds subscribed. Dr. Nansen has issued a personal appeal to the universities of the world to help to save from extinction the rapidly diminishing numbers of men in Russia who have been able to go through the ordeal of suffering to which many of them have been subjected during the past few years. May I appeal to readers of NATURE for their support of the work of the Universities' Committee?

Further detailed information, which for lack of space cannot be given here, Miss Iredale, the organising secretary, will always be glad to send on application to any reader.

In a letter to graduate members of the British universities on behalf of the men of learning of Austria an urgent appeal has been made over the following signatures of distinguished representatives. of learning:-
William Bragg,
Bryce,
A. S. Eddington,
Richard Gregorv,
Haldane of Cloan,
Frederic G. Kenyon,
Walter Lock.
Donald Macalister,
Charles J. Martin,
Henry A. Miers,

\author{
Filbert Murray, \\ E. Rutherford, \\ M. E. Sadler, \\ Arthur Schuster, \\ Napier Shaw, \\ A. E. Shipley, \\ George Adam Smith, \\ Ernest H. Starling, \\ J. J. Thomson.
}
Maurice de Bunsen, Chairman, Universities' Committee.
Fishmongers' Hall, London Bridge, E.C.4, November $2 \mathrm{r}$.

\section{Ophion luteus.}

I. BEG to thank Dr. Gahan and Dr. Stenton for their notes on this insect in Nature of November 24, p. 403. I am well aware of the importance of precision in recording the behaviour of any animal and any other natural phenomenon; wherefore I was specially careful to ascertain from the persons who had been stung by Ophion in my house whether the insects had received any provocation. In most of the cases brought to my notice (numbering three or four in each of the last five years) the person stung was asleep, and may semi-consciously have made some movement that irritated the fly. But in the case I mentioned as happening last August, the young lady was reading in bed and felt the sharp stab on her arm before she saw the fly.

Our experience of the results of the sting differs from that of M. R. du Buysson as quoted by Dr. Gahan; but, of course, individuals differ very much in susceptibility to poisonous stings. The persons stung in my house, so far as has been brought to my notice, were all young, except one lady more than forty years of age. In her case, as in the others, the sting was followed by a painful and peculiarly hard swelling which did not subside in less than twenty-four hours.

Dr. Stenton asks whether care was taken to identify the species of Ophion. I sent specimens for identification to both Dr. Gahan and Mr. J. M. Gordon, who concurred independently in pronouncing the fly to be Ophion luteus.

Herbert Maywell.

Monreith, Whauphill, Wigtownshire, N.B. NO. 27 I 8 , VOL. IO 8 ]

\section{The "Zoological Record."}

THE Zoological Record, which was founded in 1864 by English zoologists, has been issued regularly ever since, and contains each year a complete bibliography of all publications connected with zoology. It is now the sole work of the kind, and is invaluable to all workers in every branch of zoology.

Previous to 1914 the Zoological Record formed part of the "International Catalogue of Scientific Literature," and was issued under the joint responsibility of the Royal Society and the Zoological Society. As the Royal Society found itself unable to proceed with the volumes of the "International Catalogue" after the issue for I914, the Zoological Society has undertaken to prepare and issue the volumes for $19^{1} 5^{-20}$ inclusive at its sole financial risk.

It is the wish of the Record Committee of the Zoological Society to continue the publication of this most useful work, but it is obvious that it cannot expect the society to undertake the heavy financial liability involved in publication, unless it receives reasonable support from working zoologists both at home and abroad.

I hope, therefore, that all working zoologists who agree with me that the suspension of the publication of the Record would have a most disastrous effect on the progress of zoology will either subscribe themselves, or will urge the librarians of the institutions with which they are connected to do so.

A prospectus and form of subscription either for the whole or separate divisions of the Record can be had on application to the Zoological Society.

W. L. Sclater,

Editor, Zoological Record.

Zoological Society of London, London, N.W.8.

\section{Reflection from Cylindrical Surfaces.}

THE cone of light reflected from a cylindrical surface deseribed by Mr. Shaxby in Nature of November 17, p. 369, is discussed in Tait's elementary treatise on Light.

A related phenomenon, also mentioned in the same work, the explanation of which is readily deducible from the above, is of interest. I refer to the circle of light seen by refiection of a distant point source from a bundle of cylindrical surfaces. The surfaces may be of any form, the condition being that their generating lines must all be parallel to one another. The locus of points of reflection is then a conical surface containing the source, with its apex at the eye of the observer. The axis of the cone is parallel to the generating lines of the surfaces. When the line joining the eye to the source is parallel to these lines, the circle reduces to a point coinciding with the source; when at right angles, the circle becomes a great circle passing through the source.

An everyday illustration of this is to be seen in the reflection of a distant street-lamp by the closed roller shutters of a shop-window. The points of light reflected from the corrugations form an arc of a circle which if completed would pass through the lamp.

The circle of light seen when viewing a point source through certain crystals is evidently due to the same phenomenon, the crystals presumably being fibrous in structure or containing enclosures or cavities with cylindrical surfaces. Some years ago Prof. S. P. Thompson submitted some crystals having this property to a meeting of the Physical Society of London.

32 Willoughby Road, Hampstead,

C. O. Bartrum. 